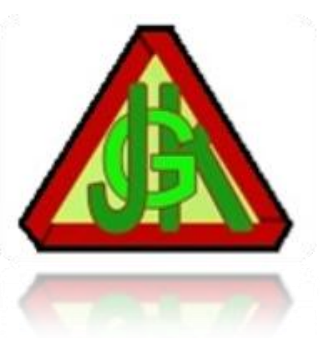

\title{
Pendidikan Kesehatan Melalui WhatsApp Group Meningkatkan Pengetahuan dan Sikap Karang Taruna Dalam Menghadapi Bencana Tsunami Di Pesisir Pantai Tanah Lot
}

\author{
Kadek Mahendra Prasetia Adinata ${ }^{1}$, I Wayan Sukawana ${ }^{2}$, IGA Ari Rasdini ${ }^{3}$, \\ I Made Sukarja $^{4}$, Ni Made Juniari ${ }^{5}$ \\ 1,2,3,4,5 Politeknik Kesehatan Kemenkes Denpasar \\ Denpasar Indonesia \\ email : dekmahendra91@gmail.com ${ }^{1}$, wsukawana@yahoo.com ${ }^{2}$, \\ rasdiniari@gmail.com ${ }^{3}$, mdsukarja@yahoo.co.id ${ }^{4}$,juniari0706@gmail.com ${ }^{5}$
}

\begin{abstract}
Abstrak
Pulau Bali terletak sangat dekat dengan zona subduksi lempeng Indo-Australia dan lempeng Eurasia yang sering memicu gempa besar bahkan diprediksi dapat menimbulkan tsunami. Tsunami merupakan serangkaian air yang disebabkan oleh perpindahan besar air di laut yang kemudian menjadi serangkaian gelombang destruktif yang kuat ketika tiba di pantai. Survey BNPB menemukan bahwa pengetahuan dan sikap masyarakat sangat kurang dalam menghadapi bencana tsunami. Tujuan penelitian ini untuk mengetahui pengaruh pendidikan kesehatan melalui WhatsApp group terhadap pengetahuan dan sikap karang taruna dalam menghadapi bencana tsunami di pesisir pantai Tanah Lot. Penelitian praeksperimental dilakukan terhadap 39 anggota karang taruna Desa Beraban, Kecamatan Kediri, Tabanan. Pendidikan kesehatan dilakukan dengan pemberian modul, ceramah menggunakan aplikasi zoom dan diskusi melalui WhatsApp group selama 1 minggu pada minggu pertama Bulan Mei 2021. Data pre dan post dikumpulkan melalui google form. Responden laki-laki sebanyak 51,3\% dan $92,3 \%$ responden berusia 18 tahun. Terjadi peningkatan skor sebesar 77,98\% dan berdasarkan uji paired t-test disimpulkan bahwa terdapat peningkatan yang signifikan (nilai sig. $=0,001$ ) terhadap tingkat pengetahuan dan sikap karang taruna dalam menghadapi bencana tsunami di pesisir pantai Tanah Lot setelah diberikan pendidikan kesehatan melalui WhatsApp group selama satu bulan. Setelah penelitian ini diharapkan tokoh karang taruna tetap melakukan update informasi melalui WhatsApp group agar memiliki pengetahuan dan sikap yang baik dalam menghadapi bencana tsunami.
\end{abstract}

Kata kunci : Pendidikan Kesehatan, WhatsApp Group, Pengetahuan, Sikap, Bencana Tsunami

\footnotetext{
Abstract

The island of Bali is located very close to the subduction zone of the IndoAustralian plate and the Eurasian plate which often triggers large earthquakes and even predicted to cause a tsunami. A tsunami is a series of water caused by a
} 
large displacement of water in the sea which then becomes a series of powerful destructive waves when it arrives at the beach. The BNPB survey found that people's knowledge and attitudes were very lack in dealing with the tsunami disaster. The purpose of this study was to determine the effect of health education through WhatsApp groups on the knowledge and attitudes of youth groups in dealing with the tsunami disaster on the Tanah Lot coast. Pre-experimental research was conducted on 39 members of the youth organization in Beraban Village, Kediri District, Tabanan. Health education is carried out by giving modules, lectures using the zoom application and discussions via WhatsApp groups for 1 week in the first week of May 2021. Pre and post data are collected via google form. Male respondents were $51.3 \%$ and $92.3 \%$ of respondents were 18 years old. There was an increase of $77.98 \%$ in the score and significant in the paired t-test (sig. value $=0.001$ ) on the level of knowledge and attitudes of youth organizations in dealing with tsunami disaster on the Tanah Lot coast after being given health education via WhatsApp group for one month. After this research, hoped that the youth leaders will continue to update information through WhatsApp groups so that they have good knowledge and attitudes in dealing with the tsunami disaster.

Keyword : Health Education, WhatsApp Group, Knowledge, Attitudes, Tsunami Disaster

\section{PENDAHULUAN}

Indonesia terletak di antara tiga lempeng utama dunia yaitu Lempeng Pasifik yang bergerak ke arah barat menuju barat laut dengan kecepatan sekitar 10 $\mathrm{cm}$ per tahun. Lempeng IndoAustralia yang bergerak ke arah utara menuju timur laut dengan kecepatan sekitar $7 \mathrm{~cm}$ pertahun, serta Lempeng Eurasia yang relatif diam, namun resultan sistem kinematiknya menunjukkan gerakan ke arah barat daya dengan kecepatan mencapai $13 \mathrm{~cm}$ pertahun ${ }^{1}$. Secara geografis Indonesia terletak pada rangkaian cincin api yang membentang sepanjang lempeng pasifik yang merupakan lempeng tektonik paling aktif di dunia. Indonesia merupakan negara kepulauan yang mempunyai busur gunung berapi terpanjang di dunia. Indonesia memiliki 127 gunung berapi aktif, atau sekitar 13\% gunung berapi aktif di dunia terletak di Indonesia. Wilayah Indonesia sangat berisiko terjadi bencana hidrometeorologi seperti tsunami sebesar $80 \%^{2}$. Tsunami merupakan serangkaian air yang disebabkan oleh perpindahan besar air di laut yang kemudian menjadi serangkaian gelombang destruktif yang kuat ketika tiba di pantai ${ }^{3}$.

Pada tahun 2017, Badan Nasional Penanggulangan Bencana (BNPB) mencatat terjadi 2.271 kejadian bencana dari awal tahun 2017 hingga 19 
Kadek Mahendra Prasetia Adinata, I Wayan Sukawana, IGA Ari Rasdini, I Made Sukarja, Ni Made Juniari. Desember 2021. 14 (2): 96-112

Desember 2017. Berdasarkan data, 148,4 juta warga tinggal di daerah rawan gempa bumi, 5 juta warga rawan terkena tsunami, dan 1,2 juta penduduk rawan erupsi gunung api. Jutaan warga juga terancam bencana hidrometeorologis. BNPB juga mengatakan bahwa ada banyak wilayah yang memiliki potensi terkena bencana alam, Merujuk pada data tersebut, ada 386 kabupaten di zona bahaya gempa bumi sedang hingga tinggi. Ada 233 kabupaten rawan tsunami, 75 kota terancam erupsi gunung api. Selain itu, terdapat pula 315 kabupaten di daerah bahaya sedang-tinggi banjir, dan 274 kabupaten daerah bahaya sedang- tinggi bencana longsor. Menurut data yang dihimpun dalam Data Informasi Bencana Indonesi (DIBI)-BNPB, terlihat bahwa dari lebih dari 1.800 kejadian bencana pada periode tahun 2005 hingga 2015 lebih dari 78\% (11.648) kejadian bencana merupakan bencana hidro meteorology dan hanya sekitar 22\% (3.810) merupakan bencana geologi ${ }^{4}$.

BNPB mencatat, selama tahun 2018, terjadi 1.999 kejadian bencana di Indonesia. Dampak yang ditimbulkan bencana dilaporkan sangat besar. Tercatat 3.548 orang meninggal dunia dan hilang, 13.112 orang luka-luka, 3,06 juta jiwa mengungsi dan terdampak bencana, 339.969 rumah rusak berat, 7.810 rumah rusak sedang, 20.608 rumah rusak ringan, dan ribuan fasilitas umum rusak ${ }^{5}$. BNPB menganalisis jumlah kejadian bencana tahun ini lebih rendah dibandingkan tahun sebelumnya, 2019. Perhitungan dari awal Januari 2019 hingga 29 Juni 2019, jumlah kejadian bencana mencapai 2.229 kali, sedangkan pada tahun ini 1.549. Ini berarti mengalami penurunan kejadian sekitar 30,5 persen ${ }^{6}$.

Pulau Bali terletak sangat dekat dengan zona tumbukan antara Lempeng Indo-Australia dan Lempeng Eurasia. Zona subduksi yang terkait merupakan sumber utama bencana Tsunami yang dapat berdampak khususnya bagian selatan pulau ini. Diperkirakan bahwa gelombang tsunami dari area ini hanya memerlukan 30 hingga 60 menit untuk mencapai pantai. Pulau Bali juga merupakan wilayah yang harus dilindungi dari indeks risiko bencana. Dimana Provinsi yang mengalami indeks risiko bencana tertinggi berada di Kabupaten Badung dengan nilai indeks risiko $179,2 \%$, disusul oleh Kabupaten Tabanan 
Kadek Mahendra Prasetia Adinata, I Wayan Sukawana, IGA Ari Rasdini, I Made Sukarja, Ni Made Juniari. Desember 2021. 14 (2): 96-112

dengan nilai indeks risiko bencana 174, 4, kemudian Kota Denpasar dan Kota Buleleng dengan hasil indeks risiko bencana yaitu 167,2 \% ${ }^{2}$.

Menurut pilot survei pengetahuan, sikap dan perilaku menghadapi bencana gempa bumi dan tsunami yang dilakukan oleh BNPB yang bekerjasama dengan Badan Pusat Statistik pada tahun 2013 menemukan bahwa pengetahuan dan sikap masyarakat dalam menghadapi bencana tsunami pada katagori kurang. Dari hasil survei ini ditemukan fakta yang perlu menjadi perhatian bersama, bahwa kurangnya pengetahuan dan sikap dalam menghadapi bencana tsunami dikarenakan sebagian besar masyarakat tidak pernah mengikuti pelatihan/seminar/simulasi/pertemuan untuk meningkatkan pengetahuan terkait dengan bencana tsunami baik laki-laki maupun perempuan, bahkan ada juga responden yang menjawab tidak tahu. Besarnya anggota yang berjenis kelamin laki-laki yang tidak pernah mengikuti pelatihan/seminar/simulasi/pertemuan untuk meningkatan pengetahuan terkait dengan bencana tsunami adalah $80,58 \%$ dan perempuan 79,25\%. Sementara itu yang menjawab tidak tahu sebesar 2,51\% anggota berjenis kelamin laki-laki dan 3,56\% anggota berjenis kelamin perempuan. Data survei juga mendapatan hasil bahwa 74,8 \% responden memilih tidak tahu tentang pengetahuan masyarakat mengenai tanda-tanda terjadinya bencana tsunami, 66,8\% responden memilih tidak mengetahui bahwa akses internet tentang sumber peringatan bencana tsunami yang akan menimbulkan kurangnya pengetahuan masyarakat terhadap sumber peringatan bencana tsunami, $68,8 \%$ responden memilih tidak mengetahui tentang pengetahuan sumber peringatan bencana tsunami yang diberikan oleh pemuka agama/pemuka masyarakat, dan $77,2 \%$ responden memilih tidak mengetahui sumber peringatan bencana yang diberikan oleh TNI/Polri/Petugas keamanan sehingga berdampak terhadap kurangnya pengetahuan masyarakat dalam sumber peringatan bencana dalam menghadapi bencana tsunami ${ }^{7}$.

Menurut Badan Meteorologi Klimatologi dan Geofisika (BMKG) (2018) mencatat selama tahun 2018 bencana Tsunami terjadi sebanyak 3 kali. Dimana pada tanggal 05 Agustus 2018 dan tanggal 28 September 2018 terjadi bencana gempa dan tsunami yang berlokasi di Lombok Utara, NTB, Donggala dan 
Kadek Mahendra Prasetia Adinata, I Wayan Sukawana, IGA Ari Rasdini, I Made Sukarja, Ni Made Juniari. Desember 2021. 14 (2): 96-112

Sulawesi Tengah sehingga dampak dari bencana tersebut sangat besar. Tercatat 2.037 orang meninggal dunia, 671 orang hilang, 4.084 orang mengalami lukaluka, 74.044 orang mengungsi, total kerusakan rumah mencapai 67.310 unit rumah rusak, 20 unit fasilitas kesehatan rusak. dan pada tanggal 22 Desember 2018 bencana alam Tsunami juga berdapak sangat besar terhadap penduduk Indonesia yang di timbulkan dari runtuhan anak gunung krakatau. Tercatat 431 orang meninggal dunia, 7.200 orang mengalami luka-luka, 15 orang hilang, 46.646 orang mengungsi, 181 unit rumah mengalami rusak ringan, 70 unit rumah rusak sedang, dan 1.572 unit rumah mengalami rusak berat ${ }^{6}$.

Adapun upaya pemerintah untuk mengatasi timbulnya bencana tsunami khususnya kerentanan masyarakat, dimana pemerintah membuatkan upaya pencegahannya dimulai dari (1) Perlindungan garis pantai, hal ini dilakukan dengan cara penetapan peraturan tentang pembangunan wilayah pantai, melestarikan hutan mangrove dengan cara tidak menebang secara sembarangan atau tidak mengubah lahan mangrove menjadi tambak. (2) Membangun sistem peringatan dini dan sistem ini akan menyebar luaskan informasi kepada penanggung jawab di wilayah dan masyarakat yang terdampak bencana ${ }^{6}$.

Menyadari tingginya tingkat kerawanan dan kerentanan terhadap tsunami, Indonesia telah berupaya meningkatkan kesiapsiagaan dalam menghadapi tsunami dengan membangun Indonesia Tsunami Early Warning System (InaTEWS) yang diprakarsai oleh Kementerian Koordinator Bidang Kesejahteraan Rakyat; Kementerian Riset dan Teknologi; Badan Meteorologi, Klimatologi, dan Geofisika (BPPT); Badan Pengkajian dan Penerapan Teknologi (BPPT), Badan Informasi Geospasial (BIG)1; dan berbagai instansi terkait lainnya dengan dibantu oleh beberapa negara sahabat seperti Jerman, Australia, Jepang, dan Amerika Serikat ${ }^{8}$.

Pendidikan kesehatan merupakan langkah utama dalam menghadapi bencana, dengan adanya pendidikan kesehatan tentu masyarakat trutama karang taruna akan meningkatkan pengetahuan dan sikap karang taruna dalam menghadapi bencana. Pendidikan kesehatan adalah semua kegiatan untuk memberikan dan meningkatkan pengetahuan, sikap, praktek baik individu, 
Kadek Mahendra Prasetia Adinata, I Wayan Sukawana, IGA Ari Rasdini, I Made Sukarja, Ni Made Juniari. Desember 2021. 14 (2): 96-112

kelompok atau masyarakat dalam memelihara dan meningkatkan kesehatan mereka sendiri ${ }^{9}$. Karang Taruna memiliki peran strategis dalam menjalin sinergi dan kerja sama kemitraan antara generasi muda dengan berbagai pihak dalam mewujudkan peningkatan kesejahteraan sosial ${ }^{10}$.

Badan Koordinasi Nasional Penanganan Bencana menguraikan bahwa kurangnya pengetahuan yang dimiliki, rendahnya sikap untuk melakukan antisipasi terjadinya bencana tsunami, perilaku negatif untuk pencegahan bencana didalam menghadapi suatu kondisi bencana yang memicu untuk terjadinya peningkatan resiko saat bencana terjadi. Edukasi mengenai resiko kejadian bencana seharusnya diberikan kepada masyarakat khususnya kepada anggota karang taruna sejak dini. Hal ini menyebabkan perlunya ada edukasi dengan menggunakan media yang disenangi oleh kelompok karang taruna ${ }^{11}$.

Penelitian dilakukan dengan menggunakan media WhatsApp group. Media ini merupakan bagian dari sosial media yang menggunakan aplikasi berbasis internet sehingga memungkinkan setiap penggunanya dapat saling berbagi berbagai macam konten sesuai dengan fitur pendukungnya. WhatsApp Messanger merupakan teknologi popular yang sangat potensial untuk dimanfaatkan sebagai alat pembelajaran. Al Saleem menambahkan bahwa dalam WhatsApp messanger terdapat WhatsApp group yang mampu membangun sebuah pembelajaran yang menyenangkan terkait berbagai topik diskusi yang diberikan oleh pengajar ${ }^{12}$.

Berdasarkan uraian diatas, peneliti ingin mengetahui apakah ada pengaruh pendidikan kesehatan melalui WhatsApp group tehadap pengetahuan dan sikap karang taruna dalam menghadapi bencana tsunami di pesisir Pantai Tanah Lot.

\section{METODE PENELITIAN}

Jenis penelitian ini adalah penelitian pra-eksperimental dengan one-group pra-post test design. Penelitian dilakukan pada bulan April - Mei 2021. Besar sampel pada penelitian ini sebanyak 39 orang anggota karang taruna Desa Beraban, Kecamatan Kediri Kabupaten Tabanan yang diambil dengan teknik acak sederhana. Setelah ditemukan subyek penelitian kemudian dilakukan penjelasan tentang proses penelitian. Subyek yang setuju dijadikan sampel penelitian 
Kadek Mahendra Prasetia Adinata, I Wayan Sukawana, IGA Ari Rasdini, I Made Sukarja, Ni Made Juniari. Desember 2021. 14 (2): 96-112

kemudian didata nomor telepon untuk dibuatkan WhatsApp group. Data pengetahuan dan sikap karang taruna dalam menghadapi bencana tsunami di pesisir pantai Tanah Lot sebelum dan setelah perlakuan dikumpulkan menggunakan google form. Google form memuat kuesioner dengan nilai uji validitas 0,76 dan hasil uji reliabilitas sebesar 0,60. Tautan google form disebarkan melalui WhatsApp group. Data pre dikumpulkan satu hari sebelum perlakuan. Responden diberikan modul melalui WhatsApp group mengenai pengertian bencana alam, kerentanan lingkungan, kerentanan bangunan fisik, serta sikap dan kepedulian masyarakat terhadap risiko bencana. Kemudian dilanjutkan dengan ceramah menggunakan aplikasi zoom. Diskusi serta umpan balik dilakukan selama satu minggu melalui WhatsApp group. Data post dikumpulkan satu hari setelah perlakuan. Uji normalitas data menggunakan uji Skewness, dan data dinyatakan berdistribusi normal. Analisa data univariat terdiri dari analisa karakteristik responden, tingkat pengetahuan dan sikap karang taruna dalam menghadapi bencana tsunami sebelum diberikan perlakuan, serta tingkat pengetahuan dan sikap karang taruna dalam menghadapi bencana tsunami setelah diberikan perlakuan. Analisis data bivariat menggunakan uji Paired T-test.

\section{HASIL DAN PEMBAHASAN}

Tabel 1. Distribusi Frekuensi Karakteristik Responden Berdasarkan Jenis Kelamin dan Usia Karang Taruna Desa Beraban, Kecamatan Kediri, Kabupaten Tabanan

Tahun 2021

\begin{tabular}{lcc}
\hline \multicolumn{1}{c}{ Data Demografi } & Frekuensi (n) & Persentase (\%) \\
\hline Jenis Kelamin & & \\
Laki-laki & 20 & 51,3 \\
Perempuan & 19 & 48,7 \\
\hline Jumlah & 39 & 100 \\
\hline Usia & 3 & 7,7 \\
17 tahun & 36 & 92,3 \\
18 tahun & 39 & 100 \\
\hline Jumlah & &
\end{tabular}

Tabel 1 menunjukan bahwa sebagian besar responden dalam penelitian ini berjenis kelamin laki-laki yaitu sebanyak 20 orang $(51,3 \%)$, dan sebagian besar 
Kadek Mahendra Prasetia Adinata, I Wayan Sukawana, IGA Ari Rasdini, I Made Sukarja, Ni Made Juniari. Desember 2021. 14 (2): 96-112

responden dalam penelitian ini berusia 18 tahun yaitu sebanyak 36 orang $(92,3 \%)$. Rata-rata skor tingkat pengetahuan dan sikap karang taruna sebelum diberikan pendidikan kesehatan melalui WhatsApp group dalam menghadapi bencana tsunami sebesar 46,00 dengan nilai standar deviasi 16,48. Gambaran klasifikasi tingkat pengetahuan dan sikap karang taruna sebelum dan sesudah diberikan pendidikan kesehatan dalam menghadapi bencana tsunami, disajikan tabel 2 .

Semakin cukup umur tingkat kematangan dan kekuatan seseorang akan lebih matang dalam berpikir dan bekerja dari segi kepercayaan masyarakat yang lebih dewasa akan lebih percaya dari pada orang yang belum cukup tinggi kedewasaannya. Hal ini sebagai akibat dari pengalaman jiwa. Karang Taruna adalah organisasi yang dibentuk oleh masyarakat sebagai wadah generasi muda untuk mengembangkan diri, tumbuh, dan berkembang atas dasar kesadaran serta tanggung jawab sosial dari, oleh, dan untuk generasi muda, yang berorientasi pada tercapainya kesejahteraan sosial bagi masyarakat ${ }^{13}$.

Tabel 2. Gambaran Tingkat Pengetahuan dan Sikap Karang Taruna dalam Menghadapi Bencana Tsunami di Pesisir Pantai Tanah Lot Sebelum dan Setelah Diberikan Perlakuan Pendidikan Kesehatan melalui WhatsApp Group

\begin{tabular}{lcccc}
\hline \multicolumn{1}{c}{$\begin{array}{c}\text { Klasifikasi } \\
\text { Pengetahuan } \\
\text { dan sikap }\end{array}$} & \multicolumn{2}{c}{ Pre-test } & \multicolumn{2}{c}{ Post-test } \\
\cline { 2 - 5 } & Frekuensi (n) & $\begin{array}{c}\text { Persentase } \\
(\%)\end{array}$ & Frekuensi (n) & $\begin{array}{c}\text { Persentase } \\
(\%)\end{array}$ \\
\hline Kurang & 24 & 61,5 & 4 & 10,3 \\
\hline Cukup & 14 & 35,9 & 12 & 30,8 \\
\hline Baik & 1 & 2,6 & 23 & 59,0 \\
\hline Jumlah & 39 & 100 & 39 & 100 \\
\hline
\end{tabular}

Tabel 2 menunjukkan bahwa sebagian besar responden (61,5\%) tingkat pengetahuan dan sikap karang taruna sebelum diberikan pendidikan kesehatan melalui WhatsApp group dalam menghadapi bencana tsunami pada klasifikasi kurang. Hasil pada penelitian ini sama dengan hasil survei BNPB tahun 2013 yang menemukan bahwa bahwa pengetahuan dan sikap masyarakat dalam menghadapi bencana tsunami pada katagori kurang ${ }^{7}$. Hasil temuan dalam penelitian ini lebih baik dengan hasil penelitian pengaruh penyuluhan terhadap tingkat pengetahuan siswa terhadap kesiapsiagaan bencana gempa bumi pada 
Kadek Mahendra Prasetia Adinata, I Wayan Sukawana, IGA Ari Rasdini, I Made Sukarja, Ni Made Juniari. Desember 2021. 14 (2): 96-112

siswa kelas III SDN Kasihan 1 Bantul, yang menyatakan bahwa lebih dari separuh responden $(74,8 \%)$ masih memiliki pengetahuan yang kurang. Perbedaan ini dapat dipengaruhi oleh perbedaan karakteristik responden, dimana penelitian diberikan kepada responden siswa yang masih duduk di kelas III sekolah dasar sedangkan penelitian ini dilakukan kepada responden anggota karang taruna yang berpendidikan $\mathrm{SMA}^{14}$.

Rata-rata skor pengetahuan dan sikap karang taruna sesudah diberikan perlakuan pendidikan kesehatan melalui WhatsApp group sebesar 81,87, nilai stadar deviasi 14,18. Sebagian besar (59\%) responden menunjukkan tingkat pengetahuan dan sikap dalam menghadapi bencana tsunami dengan klasifikasi baik setelah diberikan pendidikan kesehatan. Uji normalitas data sebelum dan setelah perlakuan dilakukan dengan uji skewnes. Hasil uji sekewnes data sebelum perlakuan sebesar 0,859 dan setelah perlakuan sebesar -1,291. Hasil penelitian ini lebih baik dari penelitian yang meneliti tentang Pengaruh Penyuluhan Kesiapsiagaan Menghadapi Bencana Gempa Bumi Terhadap Pengetahuan Siswa di SD Muhammadiyah Trisigan Murtigading Sanden Bantul, menyatakan bahwa $68,3 \%$ responden memiliki pengetahuan baik setelah mendapat konseling kesehatan $^{15}$.

Kurangnya pengetahuan dalam menghadapi bencana tsunami berdampak terhadap ekonomi masyarakat. Berdasarkan dampak kerugian ekonomi pasca bencana gempa bumi dan tsunami di Pesisir Lere Kota Palu terdiri dari berbagai kerusakan, seperti kerusakan aset dengan subjek berupa kerusakan rumah, bangunan komersial dan infrastruktur kritis. Kerugian ekonomi lainnya, yaitu kerugian bisnis dan hilangnya mata pencaharian masyarakat pesisir yang berprofesi sebagai pedagang serta hilangnya mata pencaharian masyarakat pesisir yang berprofesi sebagai nelayan ${ }^{16}$.

Selain berdampak terhadap ekonomi, kurangnya pengetahuan masyarakat dalam menghadapi bencana tsunami juga berisiko terhadap keadaan sosial yaitu, kerusakan yang berakibat kepada orang seperti kematian dan cedera, gangguan layanan makanan dan pasokan bahan bakar, gangguan layanan kesehatan dan penyediaan kesejahteraan, gangguan layanan keuangan, dan gangguan layanan 
Kadek Mahendra Prasetia Adinata, I Wayan Sukawana, IGA Ari Rasdini, I Made Sukarja, Ni Made Juniari. Desember 2021. 14 (2): 96-112

perawatan dan medis. Jenis kerusakan sosial lainnya, yaitu kehilangan kekuatan seperti banyak masyarakat yang mengalami trauma dan hilangnya pelayanan air bersih yang berada di Pesisir Lere Kota Palu. Hasil temuan diatas di ungkapkan juga dalam sebuah penelitian yang menyebutkan dampak bencana yang mengakibatkan kerusakan sosial yang menyebabkan kerusakan fisik pada tubuh korban, kehilangan atau kerusakan properti dan infrastruktur, di antara dampak sosial kepada masyarakat adalah gangguan psikososial, sosial-demografis, sosial ekonomi, dan sosial-politik ${ }^{15}$. Kematian dan cedera, hilangnya pasokan (makanan, bahan bakar, barang), hilangnya komunikasi, kehilangan kekuatan, hilangnya pelayanan air (air tawar, air hujan, air limbah), hilangnya layanan sosial (Keuangan, perawatan, medis), kerugian bisnis, hilangnya struktur sosial dan fungsinya ${ }^{16}$.

Dampak bencana terbagi atas dua yaitu dampak langsung dan yang dirasakan dalam jangka panjang. Dampak bencana yang mengakibatkan kerusakan sosial yang menyebabkan kerusakan fisik pada tubuh korban, kehilangan atau kerusakan properti dan infrastruktur, di antara dampak sosial kepada masyarakat adalah gangguan psikososial, sosial-demografis, sosial ekonomi, dan sosial-politik dan juga menyatakan bahwa bencana seperti tsunami menimbulkan kerusakan rumah penduduk, kantor-kantor, pasar, dermaga, jalan, korban jiwa, dan luka-luka. Bencana seperti gempa bumi, tanah longsor, banjir dan bencana lainnya, memiliki rentan waktu yang berbeda-beda di tiap kejadian jenis dan kejadian bencana tersebut, bencana dapat diprediksikan dan ada pula yang tidak, semua bencana tersebut memiliki dampak pada kemampuan masyarakat berupa kerusakan aset (rumah, bangunan komersial, infrastruktur kritis, bertahan hidup), kerusakan orang (kematian dan cedera) dan gangguan layanan (makanan dan pasokan bahan bakar, kesehatan dan kesejahteraan penyediaan, tertib sipil) ${ }^{16}$.

Pada dasarnya ketika bencana terjadi kerusakan dalam segi ekonomi, sosial, lingkungan, dan tata kelola akan terjadi, dimana hal tersebut juga sangat berdampak terhadap masyarakat, jika disederhanakan bahwa ketika bencana terjadi kebutuhan masyarakat untuk menjadi yang paling tangguh merupakan 
Kadek Mahendra Prasetia Adinata, I Wayan Sukawana, IGA Ari Rasdini, I Made Sukarja, Ni Made Juniari. Desember 2021. 14 (2): 96-112

keharusan. Dengan demikian, dengan adanya bencana yang terjadi minimal nya masyarakat dapat mengantisipasi dan ulet terhadap dampak bencana berikutnya. Situasi yang akan terjadi pada sebagian komunitas masyarakat dikarenakan konsekuensi dari bencana yang terjadi dimana pun terjadi, seperti: Kematian dan cedera, hilangnya pasokan (makanan, bahan bakar, barang), hilangnya komunikasi, kehilangan kekuatan, hilangnya pelayanan air (air tawar, air hujan, air limbah), hilangnya layanan sosial (Keuangan, perawatan, medis), kerugian bisnis, hilangnya struktur sosial dan fungsinya ${ }^{16}$.

Tabel 3. Gambaran Pengetahuan dan Sikap Karang Taruna dalam Menghadapi Bencana Tsunami di Pesisir Pantai Tanah Lot Indikator

\begin{tabular}{lcccccc}
\hline $\begin{array}{l}\text { Pengetahuan } \\
\text { dan sikap }\end{array}$ & $\begin{array}{c}\text { Mean } \\
\text { Pre Test }\end{array}$ & $\begin{array}{c}\text { Mean } \\
\text { Post Test }\end{array}$ & N & Selisih Mean & Nilai t & $p$ value \\
\cline { 2 - 7 } & 46,00 & 81,87 & 39 & 35,81 & $-11,939$ & 0.000
\end{tabular}

Tabel 3 menunjukan pengaruh pendidikan kesehatan melalui WhatsApp group terhadap pengetahuan dan sikap karang taruna dalam menghadapi bencana tsunami di pesisir pantai Tanah Lot yang ditunjukkan dengan skor tes meningkat sebesar 77,98\% dannilai signifikansi Paired T-Test sebesar 0,00. Dengan demikian dapat disimpulkan ada pengaruh signifikan antara pemberian pendidikan kesehatan melalui WhatsApp group terhadap pengetahuan dan sikap karang taruna dalam menghadapi bencana tsunami di pesisir pantai Tanah Lot.

Berdasarkan uji statistik dengan menggunakan Uji Paired T-Test dapat diketahui bahwa hasil penelitian menemukan bahwa sebelum diberikan pendidikan kesehatan dalam menghadapi bencana tsunami menunjukan bahwa sebagian besar $(61,5 \%)$ pengetahuan dan sikap karang taruna dalam menghadapi bencana tsunami dalam klasifikasi kurang, dan Hasil penelitian sesudah diberikan perlakuan terhadap anggota karang taruna menemukan bahwa pengetahuan dan sikap karang taruna dalam menghadapi bencana tsunami meningkat $(81,87)$ sesudah diberikan perlakuan pendidikan kesehatan. Pada uji Paired T-Test menunjukan bahwa nilai signifikansi (2-tailed) $=0,000$. Dari hasil uji statistik tersebut menunjukkan bahwa $\mathrm{H}_{0}$ ditolak $\mathrm{H}_{1}$ diterima, sehingga dapat disimpulkan 
Kadek Mahendra Prasetia Adinata, I Wayan Sukawana, IGA Ari Rasdini, I Made Sukarja, Ni Made Juniari. Desember 2021. 14 (2): 96-112

terdapat pengaruh yang positif dan signifikan antara pemberian pendidikan kesehatan melalui WhatsApp group terhadap pengetahuan dan sikap karang taruna dalam menghadapi bencana tsunami di pesisir Pantai Tanah Lot.

Hasil penelitian ini memiliki hasil sama seperti pada penelitian yang sudah dilakukan oleh para ahli sebelumnya, bahwa terdapat pengaruh pendidikan kesehatan melalui WhatsApp group terhadap pengetahuan dan sikap anggota karang taruna dalam menghadapi bencana tsunami. Penelitian lain yang melibatkan 42 responden berjudul Pengaruh Edukasi Audio Visual dan Role Play terhadap Perilaku Siaga Bencana pada Anak Sekolah Dasar menunjukkan terdapat pengaruh signifikan pemberian edukasi dengan menggunakan audio visual dan role play terhadap perilaku siaga bencana (p-value 0,000$){ }^{17}$.

Pendidikan merupakan salah satu cara untuk meningkatakan pengetahuan seseorang. Orang yang memiliki pendidikan tinggi, juga lebih cenderung mampu menganalisa informasi yang ada menjadi sebuah ilmu pengetahuan baru. Jadi dalam hal ini pendidikan kesehatan tentang pengetahuan dan sikap dalam menghadapi bencana tsunami ternyata mampu menambah pemahaman responden terhadap pengetahuan dan sikap karang taruna dalam menghadapi bencana tsunami. Pemberian pendidikan kesehatan tentang pemahaman bencana alam, pemahaman kerentanan lingkungan, pemahaman tentang kerentanan bangunan fisik dan fasilitas-fasilitas penting dalam keadaan darurat bencana serta bagaimana sikap dan kepedulian dalam menghadapi bencan tsunami juga diiringi dengan pemberian media seperti power point, leafleat, sehingga diharapkan responden tidak lagi hanya sekedar mengetahui bahwa dalam menghadapi bencana tsunami itu penting tetapi juga sudah mampu mengaplikasikan pengetahuannya menjadi tindakan yang nyata, yaitu bagaimana bertindak dan berperilaku untuk kesiapsiagaan dalam menghadapi bencana tsunami ${ }^{18}$.

Pendidikan kesehatan adalah suatu usaha untuk menolong individu, kelompok masyarakat dalam meningkatkan kemampuan perilaku untuk mencapai kesehatan secara optimal. Pendidikan kesehatan adalah suatu tindakan untuk meningkatkan kemampuan melalui pembelajaran dari tidak tahu menjadi tahu agar derajat kesehatan masyarakat meningkat. Dimana pendidikan kesehatan akan 
Kadek Mahendra Prasetia Adinata, I Wayan Sukawana, IGA Ari Rasdini, I Made Sukarja, Ni Made Juniari. Desember 2021. 14 (2): 96-112

memberikan manfaat dan tujuan dalam meningkatkan pengetahuan, kesadaran, kemauan dan kemampuan masyarakat untuk hidup sehat dan berperan aktif dalam upaya kesehatan ${ }^{18}$.

Salah satu media online yang paling sering digunakan dalam pemberian pendidikan kesehatan adalah penggunaan media WhatsApp. Aplikasi WhatsApp ini merupakan salah satu bentuk perangkat lunak yang digunakan sebagai media sosial yang menghubungkan banyak orang dalam sebuah komunikasi audio-visual dan juga didukung kemampuan chat yang relatif cepat bila dibandingkan aplikasi lainnya misalkan BBM, FB Messanger atau Yahoo Messanger. Keunggulan dari WhatsApp tersebut diantaranya dapat mengirimkan tulisan, gambar, video, audio dan pesanan suara dengan mudah sehingga menunjang pemberian pendidikan kesehatan melalui media ini ${ }^{12}$.

Kesadaran akan pentingnya pengetahuan dan sikap karang taruna dalam menghadapi bencana tsunami dapat meningkatkan tindakan individu setiap anggota karang taruna dalam melindungi dan menyelamatkan diri dari bahaya bencana tsunami. Pengetahuan dan sikap dalam mengadapi bencana berdasarkan survei yang dilakukan oleh LIPI- UNESCO/ISDR pada tahun 2006, mempunyai empat komponen yang dijadikan parameter dalam mengevaluasi pengetahuan dan sikap dalam bencana tsunami, komponen tersebut yaitu: pemahaman tentang bencana alam, pemahaman tentang kerentanan lingkungan, pemahaman tentang kerentanan bangunan fisik dan fasilitas-fasilitas penting untuk keadaan darurat bencana, sikap dan kepedulian terhadap resiko bencana tsunami. Hasil penelitian ini sesuai dengan teori yang dikemukakan oleh LIPI- UNESCO/ISDR, bahwa pengetahuan adalah faktor yang sangat penting untuk menghadapi bencana alam yang terjadi. Bencana yang sering terjadi dapat dijadikan suatu pengalaman atau pelajaran yang sangat bernilai akan pentingnya pengetahuan tentang bencana yang harus dimiliki oleh setiap individu terutama yang berada di daerah yang rawan bencana seperti lokasi penelitian ini yaitu di wilayah pesisir Pantai Tanah Lot yang merupakan daerah rawan bencana Tsunami. Pengetahuan dalam menghadapi bencana yang dimiliki sangat mempengaruhi sikap dalam mengantisipasi bencana $^{19}$. 
Kadek Mahendra Prasetia Adinata, I Wayan Sukawana, IGA Ari Rasdini, I Made Sukarja, Ni Made Juniari. Desember 2021. 14 (2): 96-112

Pengetahuan risiko mengacu pada kesadaran masyarakat akan risiko bencana. Ini mencakup namun tidak terbatas pada kesadaran akan besarnya risiko, bahaya lokal, dan keterpaparan, kerentanan dan kapasitas elemen yang berisiko terhadap bahaya lokal. Seringkali, pengetahuan risiko memberikan dorongan yang dibutuhkan untuk ketahanan masyarakat dan dorongan psikologis untuk partisipasi masyarakat dalam PRB dan mitigasi. Aspek penting dari pengetahuan risiko dan ketahanan masyarakat adalah analisis bahaya dan penilaian kerentanan karena memungkinkan masyarakat untuk merancang respons adaptif terhadap potensi bencana. Selain kapasitas adaptif, pengetahuan risiko meningkatkan respons adaptif terhadap risiko lokal melalui partisipasi masyarakat dalam pemetaan bahaya. Pentingnya partisipasi lokal dalam pemetaan bahaya adalah bahwa masyarakat memperoleh pengetahuan langsung tentang informasi spasial tentang bahaya lokal dan kerentanan mereka terhadap risiko. Partisipasi lokal dalam pengetahuan bahaya juga memberikan kesempatan untuk mengkolaborasikan pengetahuan lokal dan ilmiah untuk mengatasi kerentanan masyarakat terhadap bahaya lokal. Dalam komunitas yang rawan bencana, pengetahuan risiko lebih baik diinformasikan oleh pengetahuan tentang konsekuensi potensial dari bencana daripada sejarah terjadinya bencana. Pengetahuan risiko sangat penting dalam komunitas perkotaan di mana populasi bermigrasi dari medan yang dikenal dengan risiko yang diketahui ke lanskap yang tidak dikenal. Sejauh mana pengetahuan risiko dan partisipasi dalam manajemen bahaya mempengaruhi penyesuaian pribadi terhadap bahaya lokal terkait erat dengan bagaimana individu memandang atau menafsirkan kerentanan mereka terhadap bahaya lokal. Meskipun persepsi memainkan peran utama dalam respons pribadi terhadap potensi peristiwa bahaya, persepsi itu didukung oleh faktor sosiodemografis ${ }^{20}$.

Dalam keadaan tertentu, sumber informasi dan opini ilmiah tepercaya memengaruhi penilaian tentang risiko bencana yang mungkin terjadi. Meskipun keputusan tentang keberisikoan suatu bahaya mungkin didukung oleh sumber informasi tepercaya dan saran ilmiah tentang risiko, peran tindakan perlindungan dalam persepsi risiko tidak dapat diremehkan. Orang mengandalkan pengetahuan 
Kadek Mahendra Prasetia Adinata, I Wayan Sukawana, IGA Ari Rasdini, I Made Sukarja, Ni Made Juniari. Desember 2021. 14 (2): 96-112

ahli untuk keputusan rasional tentang risiko karena kompleksitas atau kebaruan bahaya tertentu. Namun, kredibilitas informasi, kinerja institusional dalam manajemen bahaya, dan pengalaman dan kepuasan individu dengan informasi sebelumnya menentukan tingkat kepercayaan dan keandalan informasi risiko. Selain kepercayaan pada keahlian manusia, kepercayaan pada rekayasa keras memengaruhi keputusan risiko karena orang-orang merusak risiko dan mempercayai infrastruktur yang ada untuk mengurangi risiko. Meskipun pengalaman bencana dan kepercayaan memainkan peran penting dalam persepsi risiko, keputusan risiko terus dimodifikasi oleh media dan melalui interaksi sosial antar individu. Proses ini memperkuat atau melemahkan risiko yang dirasakan selama keputusan pribadi tentang risiko tersebut ${ }^{20}$.

\section{SIMPULAN}

Sebagian besar responden dalam penelitian ini berjenis kelamin laki-laki dan berusia 18 tahun. Pengetahuan dan sikap responden sebelum diberikan pendidikan kesehatan untuk meningkatkan pengetahuan dan sikap karang taruna dalam menghadapi bencana tsunami menunjukan bahwa sebagian besar pada klasifikasi kurang. Setelah diberikan pendidikan kesehatan melalui WhatsApp group, responden menunjukan tingkat pengetahuan dan sikap dalam menghadapi bencana tsunami dengan klasifikasi baik Ada pengaruh positif, dan signifikan antara pemberian pendidikan kesehatan melalui WhatsApp group terhadap pengetahuan dan sikap karang taruna dalam menghadapi bencana tsunami. Dengan demikian dapat disimpulkan ada pengaruh signifikan antara pemberian pendidikan kesehatan melalui WhatsApp group terhadap pengetahuan dan sikap karang taruna dalam menghadapi bencana tsunami di pesisir Pantai Tanah Lot.

\section{UCAPAN TERIMAKASIH}

Terimakasih kepada Kepala Desa di Desa Beraban, staf dan pegawai kantor Desa Beraban, Karang Taruna Gapera Desa Beraban yang bersedia menjadi responden pada penelitian di Desa Beraban. 
Kadek Mahendra Prasetia Adinata, I Wayan Sukawana, IGA Ari Rasdini, I Made Sukarja, Ni Made Juniari. Desember 2021. 14 (2): 96-112

\section{ETIKA PENELITIAN}

Etika penelitian ini diperoleh dari Poltekkes Kemenkes Denpasar. Nomor surat : LB.02.03/EA/KEPK/0265/2021

\section{DAFTAR RUJUKAN}

1. Rahmat HK, Pratikno H, Andrianti F, Gustaman I. Persepsi Risiko dan Kesiapsiagaan Rumah Tangga dalam Menghadapi Bencana Tanah Longsor di Kecamatan Sukaraja Kabupaten Bogor. Ilm Ilmu Sos dan Hum. 2020;6(2):25-31.

2. BNPB DP. Penurunan Indeks Risiko Bencana di Indonesia. 2016;1-31.

3. Pratiwi D, Fitri A. Analisis Potensial Penjalaran Gelombang Tsunami di Pesisir Barat Lampung, Indonesia. J Tek Sipil ITP. 2021;8(1):29-37.

4. Amri MR, Yulianti G, Yunus R, Wiguna S, W. Adi A, Ichwana AN, et al. Rbi (Risiko Bencana Indonesia). Bnpb Direktorat Pengurangan Risiko Bencana. 2018;9(3):1-218.

5. Badan Meteorologi Klimatologi dan Geoofisika. Indonesia Tsunami Early Warning System. 2018;

6. $\quad$ BMKG. Katalog Tsunami Indonesia Tahun 416-2018. 2018. 99 p.

7. (BNPB) BNPBBPS (BPS); UNPF (UNFPA). Pilot Survei Menghadapi Bencana Kota Padang 2013. 2013;

8. Ye L, Kanamori H, Rivera L, Lay T, Zhou Y, Sianipar D, et al. The 22 December 2018 tsunami from flank collapse of Anak Krakatau volcano during eruption. Sci Adv. 2020;6(3):1-9.

9. Notoatmojo. Pendidikan Kesehatan. Jakarta: Rineka Cipta; 2012.

10. Menteri Sosial Republik Indonesia. Peraturan Menteri Sosial Republik Indonesia Tentang Karang Taruna; 2019 p. 33-5.

11. Bakornas PB. Pengenalan Karakteristik Bancana dan Upaya Mitigasinya Di Indonesia. Jakarta: Direktorat Mitigasi; 2007. 33 p.

12. Jumiatmoko M. Whatsapp Messenger Dalam Tinjauan Manfaat Dan Adab. Wahana Akad J Stud Islam dan Sos. 2016;3(1):51.

13. Nursalam. Konsep dan Penerapan Metodologi Penelitian Ilmu Keperawatan. Jakarta: Salemba Medika; 2011.

14. Prb B, Pengetahuan T. Pengaruh Pelatihan Program Pengurangan Risiko Bencana (Prb) Terhadap Pengetahuan Dan Sikap Siswa Sd Negeri 3 Tangse Dalam Menghadapi Gempa Bumi. J Kedokt Syiah Kuala. 2016;16(2):74-9.

15. Chong NO, Kamarudin KH, Abd Wahid SN. Framework Considerations for Community Resilient Towards Disaster in Malaysia. Procedia Eng. 2018;212:165-72.

16. Fauzi M, Mussadun. Dampak Bencana Gempa Bumi Dan Tsunami Di Kawasan Pesisir Lere. J Pembang Wil dan Kota. 2021;17(1):16-24.

17. Sari DP. Pengaruh Edukasi Audio Visual Dan Role Play Terhadap Perilaku Siaga Bencana Pada Anak Sekolah Dasar. J Holist Nurs Sci. 2019;6(2):1-8.

18. Notoatmodjo S. Kesehatan Masyarakat Ilmu \& Seni. Jakarta: Rineka Cipta; 2011. 
Kadek Mahendra Prasetia Adinata, I Wayan Sukawana, IGA Ari Rasdini, I Made Sukarja, Ni Made Juniari. Desember 2021. 14 (2): 96-112

19. Triyono, Kurniah, Nina A, Titik K, Novi H. Pedoman Kesiapsiagaan Menghadapi Gempa Bumi dan Tsunami Berbasis Masyarakat. Badan Nas Penanggulangan Bencana. 2014;(December).

20. Odiase O, Wilkinson S, Neef A. Risk of a disaster: Risk knowledge, interpretation and resilience. J Disaster Risk Stud. 2020;12(1):a845. 